\title{
Diet and resource sharing by two Pimelodidae species in a Southeastern Brazilian reservoir
}

\author{
Zoraia Silva $^{1 *}$, Patrícia Elaine Cunha do Nascimento ${ }^{1}$, Jean Ricardo Simões Vitule ${ }^{2}$, Fabrício de Andrade \\ Frehse $^{2}$, Mayara Silva Oliveira Ferraz ${ }^{3}$ \& Lea Rosa Mourgués-Schurter \\ ${ }^{1}$ Naturali Consultoria Ambiental, R. Dr. Armando Amaral 247, 37200000, Lavras, MG, Brasil \\ ${ }^{2}$ Universidade Federal do Paraná, Departamento de Engenharia Ambiental, Laboratório de Ecologia e \\ Conservação, 81531980, Curitiba, PR, Brasil \\ ${ }^{3}$ Universidade Federal de Lavras, Departamento de Entomologia, Campus da UFLA, 37200000, \\ Lavras, $M G$, Brasil \\ ${ }^{4}$ Universidade Federal de Lavras, Departamento de Biologia, Campus da UFLA, 37200000, \\ Lavras, $M G$, Brasil \\ *Corresponding author: Zoraia Silva, e-mail: zoraia.silva@uol.com.br
}

SILVA, Z., NASCIMENTO, P.E.C., VITULE, J.R.S., FREHSE, F.A., OLIVEIRA, M.S., MOURGUÉS-SCHURTER, L.R. Diet and resource sharing by two Pimelodidae species in a Southeastern Brazilian reservoir. Biota Neotropica. 19(3): e20180675. http://dx.doi.org/10.1590/1676-0611-BN-2018-0675

\begin{abstract}
Fish can vary their diet and feeding dynamics according to biotic and abiotic factors. There is insufficient knowledge regarding these factors in reservoirs, which limits the management of these areas. The aim of this study was to determine the diet of two related and most collected fish species, verify the influence of biotic and abiotic factors on their diet, and also verify the existence of resource sharing by them in an upstream Brazilian reservoir. Fish abundance in the reservoir was calculated and data were provided by 176 specimens of Iheringichthys labrosus (Lütken, 1874) and 255 specimens of Pimelodus maculatus Lacépède, 1803 collected in Camargos reservoir, MG, Brazil. Stomach contents were analysed through the frequency of occurrence and volumetric methods. PERMANOVA analysis was done to evaluate the influence of biotic (Species and Size class) and abiotic factors (Season and Site) on the diets. The Alimentary Index (AI) and feeding overlap Index (Pianka) were also estimated. ANMDS analysis was conducted to visualize the food categories responsible for interspecific difference. The ingested items were grouped into 18 categories, of which 17 were found in both species. Feeding resources were significantly related to the biotic (Species: Pseudo $\mathrm{F}=2.583, \mathrm{P}=0.001$; Size Class: Pseudo $\mathrm{F}=1.646, \mathrm{P}=$ 0.001 ) and abiotic (Season: Pseudo $\mathrm{F}=2.458, \mathrm{P}=0.006$ ) factors. I. labrosus showed an invertivorous diet while $P$. maculatus an omnivorous diet and both species were not exclusively benthophagus as typically reported. Food overlap occurred intraspecifically and interspecifically (Pianka 0.61 to 0.97 and 0.61 to 0.66 , respectively) and overlap also occurred in three of the four analysed seasons (Pianka 0.66 to 0.91 ). The diet overlap found between two of the most fished species and the low fish productivity may indicate the limitation of resources in this reservoir and should be considered for management of this area.
\end{abstract}

Keywords: Feeding ecology, Iheringichthys labrosus, Pimelodus maculatus, Rio Grande Basin, upstream reservoir.

\section{Alimentação e compartilhamento de recursos por duas espécies de Pimelodidae em um reservatório do sudeste brasileiro}

Resumo: Os peixes podem variar suas dietas e dinâmicas alimentares de acordo com fatores bióticos e abióticos. $\mathrm{O}$ conhecimento insuficiente desses fatores em reservatórios limita o manejo dessas áreas. $\mathrm{O}$ objetivo deste estudo foi determinar a dieta de duas espécies de peixes aparentados e mais coletados; verificar a influência de fatores bióticos e abióticos na dieta, e também verificar a existência da partilha de recursos entre essas espécies em um reservatório brasileiro de cabeceira. A abundância de peixes foi calculada e dados foram fornecidos por 176 espécimes de Iheringichthys labrosus (Lütken, 1874) e 255 espécimes de Pimelodus maculatus Lacépède, 1803 coletados no reservatório de Camargos, MG, Brasil. O conteúdo estomacal foi analisado pelos métodos de frequência de ocorrência e volumétrico. A análise de PERMANOVA foi realizada para avaliar a influência de fatores bióticos (Espécies e Classe de tamanho) e abióticos (Estação e Local) nas dietas. O Índice Alimentar (IA) e o Índice de sobreposição alimentar (Pianka) também foram estimados. Uma análise de NMDS foi conduzida 
Silva, Z. et al.

para visualizar as categorias alimentares responsáveis pela diferença interespecífica. Os itens ingeridos foram agrupados em 18 categorias, das quais 17 foram encontradas em ambas as espécies. Os recursos alimentares foram significativamente relacionados aos fatores bióticos (Espécies: Pseudo $\mathrm{F}=2.583, \mathrm{P}=0.001$; Classe de tamanho: Pseudo $\mathrm{F}=1.646, \mathrm{P}=0.001$ ) e abióticos (Estação: Pseudo $\mathrm{F}=2.458, \mathrm{P}=0.006$ ). I. labrosus mostrou uma dieta invertívora e $P$. maculatus uma dieta onívora e ambas as espécies não foram exclusivamente bentófagas como normalmente descritas. A sobreposição alimentar ocorreu intraespecífica e interespecífica (Pianka 0,61 a 0,97 e 0,61 a 0,66 , respectivamente) e a sobreposição também ocorreu em três das quatro estações analisadas (Pianka 0,66 a 0,91). A sobreposição de dieta encontrada entre duas das espécies mais pescadas e a baixa produtividade pesqueira podem indicar a limitação de recursos nesse reservatório e devem ser consideradas para o manejo dessa área.

Palavras-chave: Ecologia alimentar, Iheringichthys labrosus, Pimelodus maculatus, Bacia do Rio Grande, reservatório de cabeceira.

\section{Introduction}

Fish ecology studies provide information on species biology and the dynamics of aquatic ecosystems. This in turn contributes to the development of measures for the conservation and management of fishery resources (Braga et al. 2012, Martins et al. 2017). Fish present different adaptations in their feeding habits, usually associated with spatial and seasonal changes in food availability (Wooton 1992). Thus, it is necessary to consider the influence of biotic and abiotic factors for a more accurate evaluation of their trophic ecology (Prejs \& Colomine 1981, Vitule et al. 2008). The role of biotic and abiotic factors structuring freshwater fish communities was demonstrated by Magnan et al. (1994) and Jackson et al. (2001). Magnan et al. (1994) also reported the importance of works that simultaneously analyse the biotic, abiotic and spatial factors to determine the resource use by a species. In addition, resource partitioning regulates the biomass and the functioning of the Neotropical ichthyofauna (Abilhoa et al. 2016) and its study contributes to a better understanding of how species interact (Ross 1986).

The growing number of hydroelectric plants built in Brazil since the 1950s has made necessary to study the ichthyofauna in reservoirs. However, the dispersed and fragmented nature of these studies in time and space (Agostinho et al. 2007, Agostinho et al. 2016) compromises the correct management of reservoirs, especially with the growing demand for its multiple uses (Tundisi \& Matsumura-Tundisi 2003).

The influence of biotic and abiotic factors on food resources was studied in some Brazilian reservoirs (Arcifa et al. 1992, Araújo et al. 2005, Pamplin et al. 2006). However, according to Araújo-Lima et al. (1995), trophic structure trends in reservoirs are associated to the characteristics of each reservoir. Food resource partitioning by related fish species has already been studied in Brazilian natural environments (Bonato \& Fialho 2014, Abilhoa et al. 2016) and reservoirs (Arcifa et al. 1991, Albrecht et al. 2009). However, studies on the long-term consequences of impoundment are necessary to establish feeding ecology patterns in reservoirs (Luz-Agostinho et al. 2006, Hahn \& Fugi 2007).

Both Iheringichthys labrosus (Lütken, 1874) and Pimelodus maculatus Lacépède, 1803 can be found among the native species of the Grande River. They belong to the order Siluriformes, family Pimelodidae, have common anatomical characteristics described by Lundberg \& Littmann (2003) that are generally associated with benthic foraging habits (Nomura et al. 1972, Fugi et al. 1996, Abes et al. 2001, Fugi et al. 2001). I. labrosus has been classified as omnivorous, invertivorous or insectivorous species (Manetta et al. 2003, Luz-Agostinho et al. 2006, Fagundes et al. 2008, Ribeiro et al. 2014) and there is little information on its interaction with other species (Masdeu et al. 2011). P. maculatus is usually classified as an (opportunistic) omnivorous species (Basile-Martins et al. 1986, Silva et al. 2007) with tendency towards piscivory in rivers (Andrade \& Braga 2005) or insectivory in reservoirs (Luz-Agostinho et al. 2006).

In the ichthyofauna surveys conducted between 1991 and 1995 in the Camargos reservoir, I. labrosus and P. maculatus were among the most collected species. In light of the numerous Brazilian reservoirs, it is important to understand the use of the resources, their variation and interaction among the most abundant fish species. Thus, the aim of the present study was: i) to determine the diet of I. labrosus and $P$. maculatus; ii) verify the influence of biotic and abiotic factors and iii) verify the existence of resource sharing between species, such $I$. labrosus and P. maculatus, in the Camargos reservoir, MG, Brazil.

\section{Materials and Methods}

\section{Study area}

The upper Paraná River basin, located in Southeastern Brazil, is the most affected basin by dams in the country and in the Grande River, one of its largest tributaries, there are 71 hydroelectric plants in operation (IPT 2008). The Camargos hydroelectric plant, which started operating in 1960, is the most upstream of the 12 plants located along the mainstream of the Rio Grande but licensing assessment for other upstream construction was underway (IPT 2008). Camargos is a storage reservoir (average water retention time of 58.8 days) that has a dendritic aspect with an area of $74 \mathrm{~km}^{2}$ and volume maximum of $672 \times 10^{6} \mathrm{~m}^{3}$ at an altitude of $913 \mathrm{~m}$ above sea level. This reservoir located in the upper section of the river has characteristics typical of many old, deep reservoirs (maximum depth of $32 \mathrm{~m}$ ) as described by Agostinho et al. (2007), such as thermal and dissolved oxygen (DO) stratification (DO ranging from $6.2 \mathrm{mg} / \mathrm{l}$ at the bottom to $13.4 \mathrm{mg} / \mathrm{l}$ in the middle of the photic zone) (SISÁGUA, 2018). Additionally, the surrounding area is dominated by degraded native pasture (grass).

The region under the influence of the Camargos reservoir has transitional features between $\mathrm{Cwb}$ and $\mathrm{Cwa}$ according to Köppen-Geiger climate classification (Antunes 1986). These features are characterised by two distinct periods: one warmer and rainy (spring and summer: 
October to March) and other less warm and dry (autumn and winter: from April to September) (Guimarães et al. 2010). The reservoir is at its highest level in autumn (April, May and July) due to the accumulation of summer rains. The lowest level occurs in spring (October, November and December) along with energy production prior to the next rainy season (Fig. 1). In this reservoir, three study sites were established after local investigation and fishing pre-test considering the different distances of the dam, the physical properties of the sites and the surrounding area (Table 1, Fig. 2).

\section{Data collection and laboratory procedures}

Twenty-four monthly samples were taken between February 1991 and January 1993. They occurred alternately in the three study sites and four seasons of the year, so that each site was sampled once per season in each year of study. In each sample, approximately $1200 \mathrm{~m}^{2}$ of gill nets (20 m long and 1.6 to $1.8 \mathrm{~m}$ high), having sizes of 3, 4, 5, 6, $7,8,10,12,14$ and $16 \mathrm{~cm}$ between opposing nodes, were set up in the late afternoon and removed the next morning. When it was possible, complementary trawling was also used to capture smaller specimens ( 5 $\mathrm{m}$ long, $1.5 \mathrm{~m}$ high and $5 \mathrm{~mm}$ mesh, used for $1 \mathrm{~h}$ ). Thirty seven species were collected and the fish abundance in the reservoir was obtained by the catch per unit effort (CPUE) in number (CPUEn = number of fishes caught $/ 100 \mathrm{~m}^{2} / 12 \mathrm{~h}$ ) and biomass (CPUEb = weight of fishes caught in $\mathrm{kg} / 100 \mathrm{~m}^{2} / 12 \mathrm{~h}$ ). At the end of the 24 monthly samples, 1298 individuals of I. labrosus and 405 of P. maculatus were captured.

In the field, all collected fishes were kept in ice. They were subsequently labelled, identified, measured and dissected. The stomach was removed and fixed in $4 \%$ formalin for further analysis. The specimens were selected for the current study considering the species, site, capture date and different sizes. The number of size classes was defined to avoid the low representation of the largest individuals within the population (Chipps \& Garvey 2007). Thus, three size classes were defined according to their total length: A = Small (I. labrosus between $60.0-116.0 \mathrm{~mm}, \mathrm{n}=60$ and $P$. maculatus between $49.0-149.6 \mathrm{~mm}$, $\mathrm{n}=94$ ); $\mathrm{B}=$ Medium (I. labrosus between $116.1-186.0 \mathrm{~mm}, \mathrm{n}=78$ and P. maculatus between $149.7-239.9 \mathrm{~mm}, \mathrm{n}=103)$ and $\mathrm{C}=$ Large $(I$. labrosus between $186,1-256.0 \mathrm{~mm}, \mathrm{n}=30$, and $P$. maculatus between 240.0 - $390.4 \mathrm{~mm}, \mathrm{n}=37$ ).

In the laboratory, each selected stomach was opened in a gridded Petri dish under and then assigned its Repletion State (RS) in one of five stages: $0=$ empty stomach; $1=$ stomach $1 \%$ to $25 \%$ full; $2=$ stomach $26 \%$ to $50 \%$ full; $3=$ stomach $51 \%$ to $75 \%$ full and $4=$ stomach above $76 \%$ full. Stomach contents were analysed using the volumetric (quantitative) and frequency of occurrence (qualitative) methods proposed by Hynes (1950). For this, food items of each stomach were identified and quantified under optical microscope, whose volume was fractionated within the RS value and later grouped into categories. The volumetric data tabulation provided information for the calculation of frequency of occurrence. The use of cumulative prey curves determined the number of stomachs with food to be analysed (Chipps \& Garvey 2007) and adding the stomach without food, at the end 176 specimens of I. labrosus and 255 of $P$. maculatus were used.

\section{Data analysis}

In order to analyse the diet of the two species and the influence of biotic (Species and Size class) and abiotic factors (Season and Site) the PERMANOVA analysis (Anderson et al. 2008) was performed. In order to carry out this analysis, we first transformated the volume data to log $(\mathrm{X}+1)$. After this, a similarity matrix was created using the Bray-Curtis index and the analytical design with hierarchical factors: Season (four levels, fixed); Site (three levels, random) nested in Season; Species (two levels, random) nested in Season and Site; and Size class (three levels, random) nested in Species. The relative importance of each category was presented for PERMANOVA significant results through the Alimentary Index (AIi) (Kawakami \& Vazzoler 1980):

$$
A I_{i}=\frac{F_{i} \times V_{i}}{\sum_{i=1}^{L} F_{i} \times V_{i}}
$$

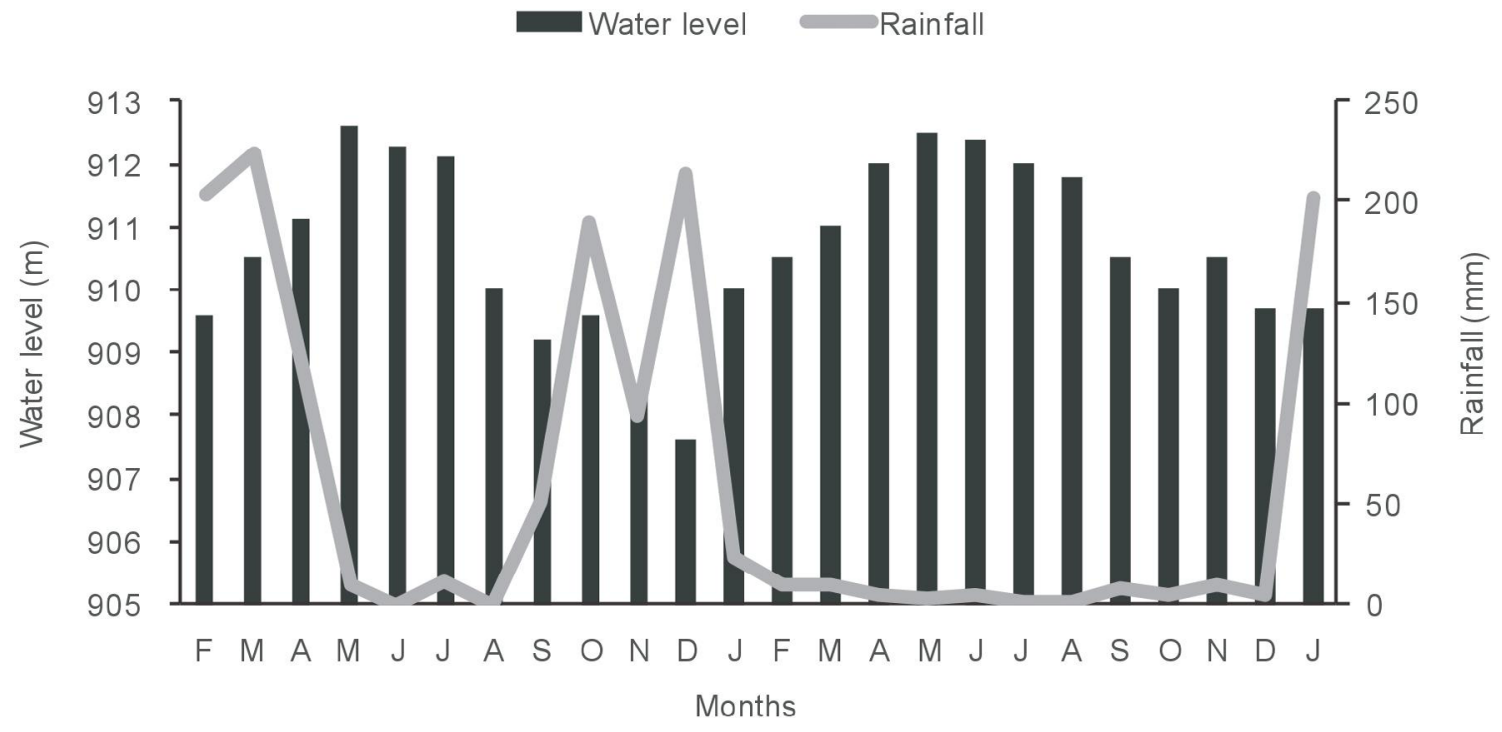

Figure 1. Rainfall and water level from February 1991 up to January 1993 at Camargos reservoir, MG, Brazil 
Table 1. Site description, Camargos reservoir, MG, Brazil

\begin{tabular}{|c|c|c|c|c|c|c|}
\hline Site & $\begin{array}{l}\text { Distance from } \\
\text { the dam }(\mathrm{km})\end{array}$ & Channel/ Margin & $\begin{array}{c}\text { Maximum } \\
\text { depth }(m)\end{array}$ & $\begin{array}{c}\text { Mean } \\
\text { depth }(m)\end{array}$ & Environment & Surrounding area \\
\hline 1 & 1 & $\begin{array}{l}\text { Main channel/left } \\
\text { margin }\end{array}$ & 18.6 & 7.4 & Lentic & Degraded native pasture \\
\hline 2 & 7 & $\begin{array}{l}\text { Side channel/right } \\
\text { margin }\end{array}$ & 13.8 & 5.4 & Backwater/ lentic & $\begin{array}{l}\text { Group of vacation homes, few banks of aquatic } \\
\text { plants; small riparian and semideciduous forest }\end{array}$ \\
\hline 3 & 13 & $\begin{array}{l}\text { Main channel/right } \\
\text { margin }\end{array}$ & 16.2 & 7.2 & Temporally lotic & $\begin{array}{l}\text { Permanent tributary; small riparian and } \\
\text { semideciduos forest }\end{array}$ \\
\hline
\end{tabular}
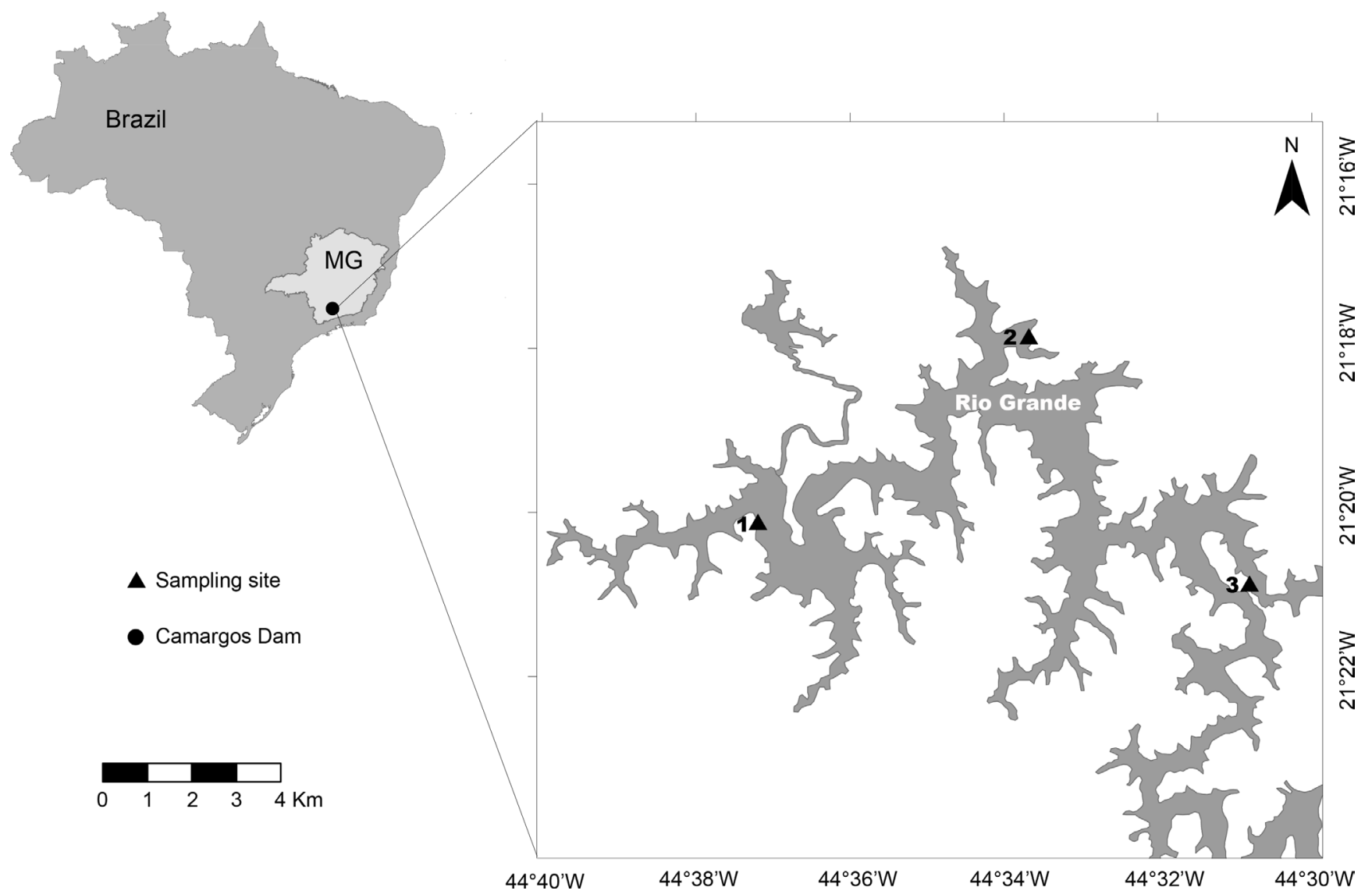

Figure 2. Map of study region showing sampling sites (1, 2 and 3), along Camargos reservoir, MG, Brazil

where $i=1,2,3, \ldots \mathrm{n}$ given food category; $L=$ number of categories; $F i=$ Frequency of occurrence of category $i(\%)$ and $V i=$ relative volume of category $i(\%)$. Resource sharing was measured by the similarity of the species diet using Pianka Index (Pianka 1974):

$$
O_{j k}=\frac{\sum_{i}^{n} P_{i j} P_{i k}}{\sqrt{\sum_{i}^{n} P_{i j^{2}} \sum_{i}^{n} P_{i k^{2}}}}
$$

where $O j k=$ Pianka overlap measure between species $j$ and $k$; Pij and Pik $=$ Proportion of resource $i$ in a total of resources used by species $j$ and $k$, respectively and $n=$ number total of categories. The visualization of food category responsible for the interspecific difference was done through the Non-metric multidimensional scaling (NMDS) analysis (Clarke \& Gorley 2006).

\section{Results}

Camargos reservoir presented mean catch per unit effort (CPUE) of 11.8 individuals $/ 100 \mathrm{~m}^{2}$ of gill net $/ 12 \mathrm{~h}$ and $0.58 \mathrm{~kg} / 100 \mathrm{~m}^{2}$ of gill net/12h. I. labrosus and P. maculatus represented the first (36.1\%) and third $(9.1 \%)$ species most collected with gill nets.

Food was found in 119 of the 176 stomachs (67.6\%) of I. labrosus and in 234 of the 255 stomachs (91.8\%) of P. maculatus. While the proportion of empty stomachs increased throughout ontogeny in $I$. labrosus, this increase was not observed in P. maculatus (Fig. 3). The ingested items were grouped into eighteen food categories, seventeen of which were found in both species and greater diversity of items, within the categories, was recorded for $P$. maculatus (Table 2). Influences of the biotic and abiotic factors tested through PERMANOVA (Table 3) indicated that there were differences in diet associated with species (Pseudo $\mathrm{F}=2.583, \mathrm{P}=0.001$ ), size class (Pseudo $\mathrm{F}=1.646, \mathrm{P}=0.001$ ) and season (Pseudo $\mathrm{F}=2.458, \mathrm{P}=0.006$ ). 
1. labrosus

With food Empty

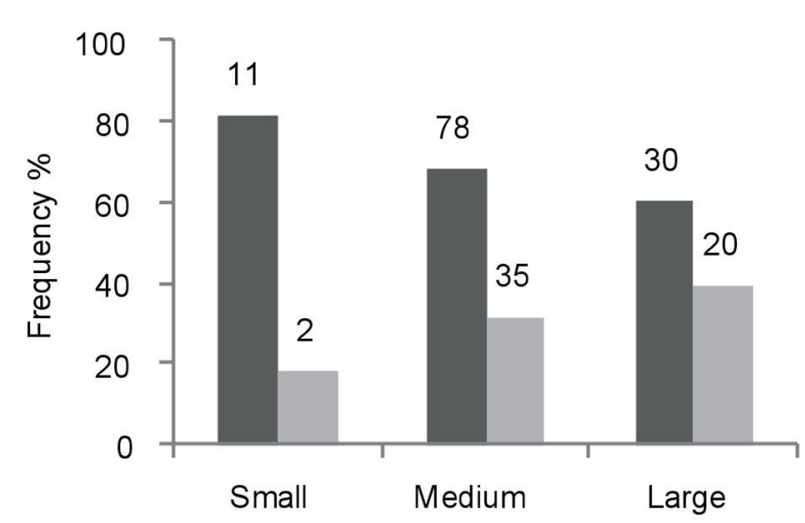

P. maculatus

With food Empty

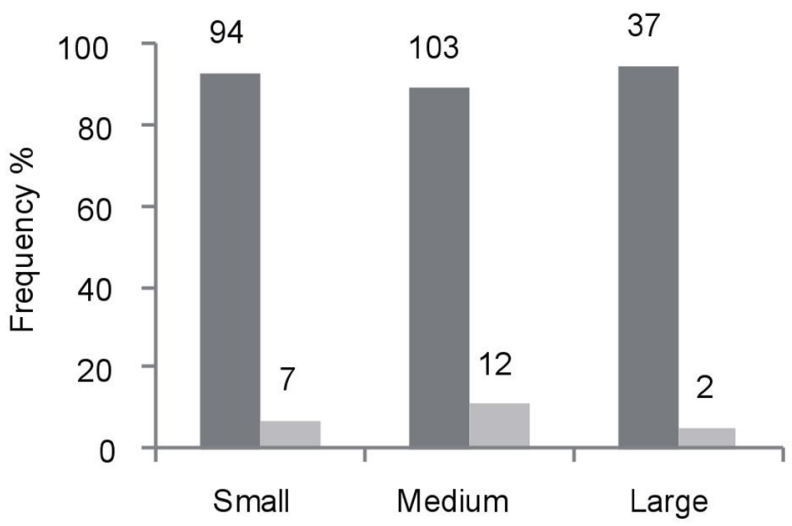

Figure 3. Percentage and number of stomachs with and without content in the three size classes of I. labrosus and P. maculatus at Camargos reservoir, MG, Brazil

Table 2. List of Identified taxa in the diet of I. labrosus and P. maculatus and their contribution in the frequency of occurrence (FO\%) and volume (V\%) at Camargos reservoir, MG, Brazil

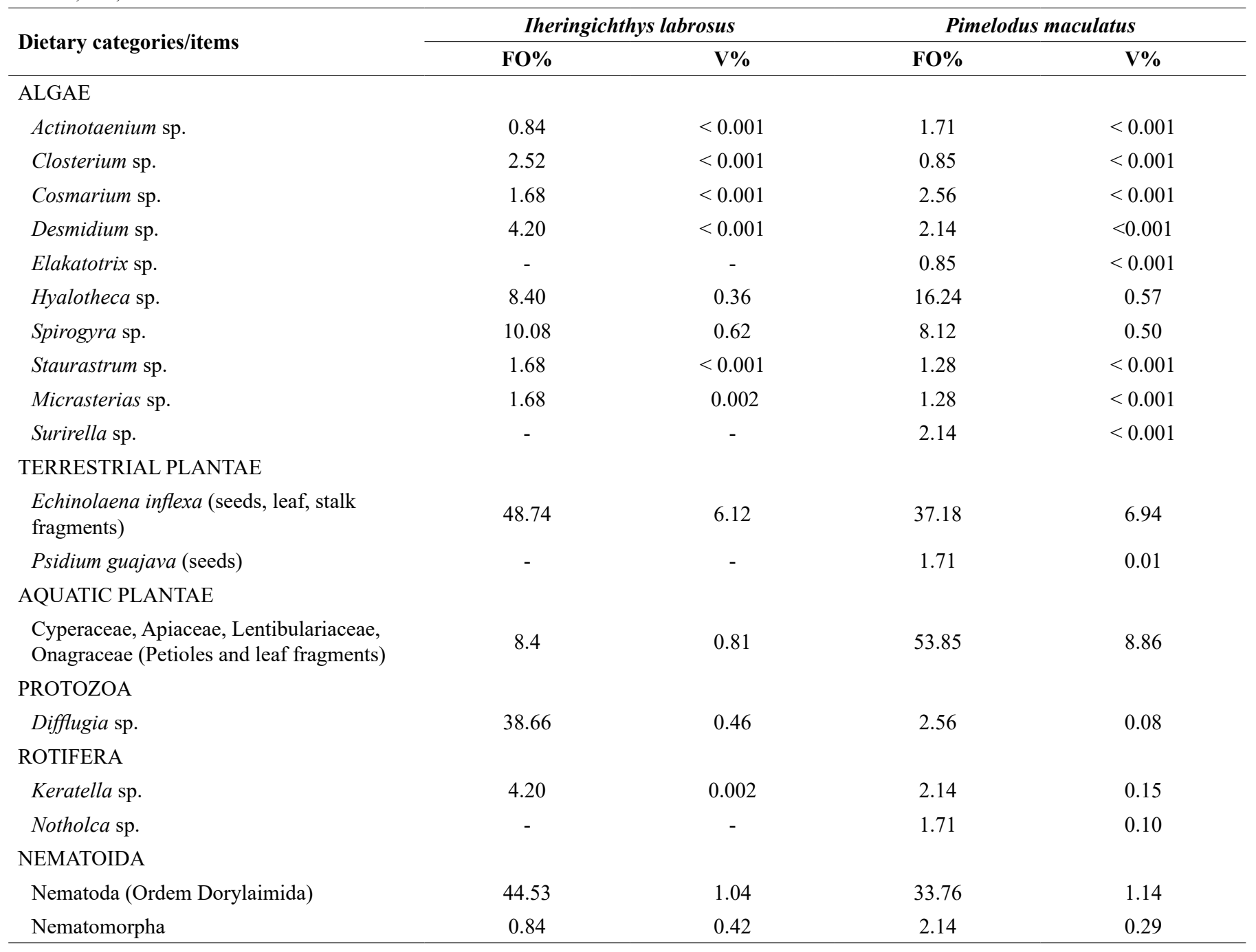


Silva, Z. et al.

Continuation Table 2.

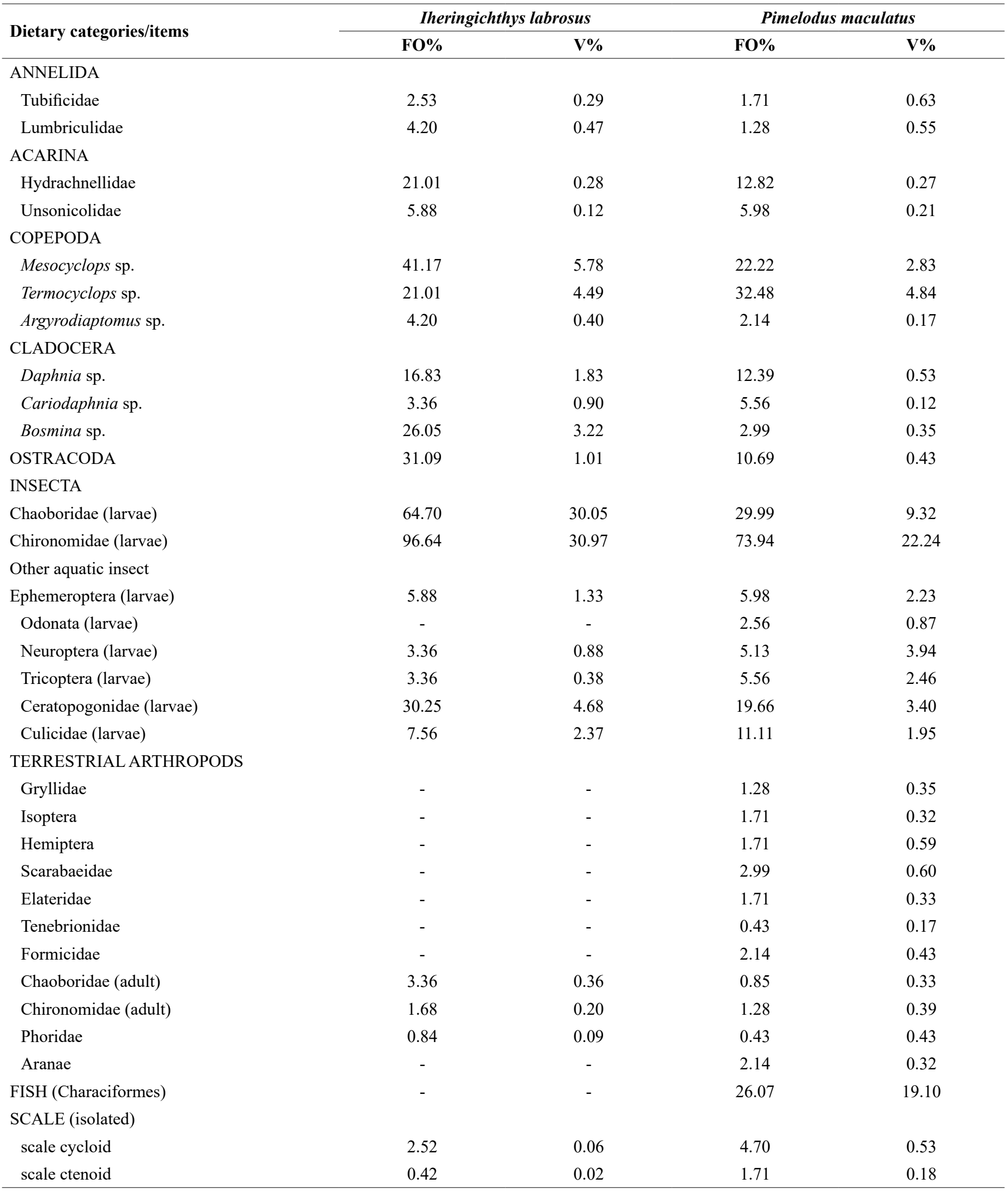


Table 3. Result of PERMANOVA analysis for use of food resources by I. labrosus and P. maculatus at Camargos reservoir, MG, Brazil

\begin{tabular}{lccccc}
\hline Sources & d.f. & SS & Pseudo-F & $\begin{array}{c}\text { P } \\
\text { (perm) }\end{array}$ & $\begin{array}{c}\text { Uniq } \\
\text { perms }\end{array}$ \\
\hline Se & 3 & 26298 & 2.458 & $0.006^{*}$ & 997 \\
Sit (Se) & 8 & 30356 & 0.562 & 0.981 & 997 \\
Sp (Sit (Se)) & 11 & 78070 & 2.583 & $0.001 *$ & 999 \\
Siz (Sp (Sit (Se))) & 34 & $1.0876 \mathrm{ES}$ & 1.646 & $0.001 *$ & 998 \\
Res & 296 & $5.7535 \mathrm{ES}$ & & & \\
Total & 352 & $8.7055 \mathrm{ES}$ & & & \\
\hline
\end{tabular}

Sources: Se- Season; Sit: Site; Sp- Species; Siz- Size class; d.f.-degrees of freedom; SS- sum of squares; $\mathrm{P}$ (perm) -probabilility; uniq perms- permutations performed; * significant results.

Considering the Alimentary Index (AI - Table 4), it can be observed the dominance of invertebrate animal categories in the diet of I. labrosus, whereas in P. maculatus animal and vegetal categories presented a more even importance. Among the categories shared by the species, some variations relating to size classes and season can be highlighted. Both terrestrial and aquatic plants were important resources in the diet of smaller individuals of $P$. maculatus and also important for all size classes in the autumn and summer seasons. The microcrustaceans were more important in the diet of the smaller individuals for both species and in the seasons of winter and spring. With regards to insects, Chironomidae were more consumed by the smaller individuals of both species. Conversely, Chaoboridae were consumed in greater quantity by the larger individuals of both species, besides being the category of greater representation during the summer for I. labrosus.
The intraspecific and interspecific diet similarities were evidenced through the size classes, with the former presenting higher values (Table 5). Between the two species, diet similarities were observed in three of the four seasons, with higher values in winter. The differentiation among the species diet appears only during the summer. The food categories that most contributed to the differences among the species were Fish, Chaoboridae, Other aquatic insect, Chironomidae and Copepoda (Fig. 4).

\section{Discussion}

The Camargos reservoir has low fish productivity, even when compared to other Brazilian reservoirs (Agostinho et al. 2007). Our results allow the classification of I. labrosus and P. maculatus as invertivorous and omnivorous species, respectively. The largest population of I. labrosus, a invertivorous fish species in the Camargos reservoir, also differs from other Brazilian reservoirs (Agostinho et al. 2007), where the success of generalist species such as P. maculatus is widely reported in the literature (Agostinho et al. 2008) due to their greater colonization capacity (Sá-Oliveira et al. 2014).

The proportion of empty stomachs can also give information about the autoecology of the fish species (Vinson \& Angradi 2011). In this way, the diet diversification of $P$. maculatus including the consumption of food with nondigestible fractions, such as vegetation (Vitule et al. 2008), reduces the proportion of empty stomachs in this species. In contrast, I. labrosus showed an increase in empty stomachs through ontogenetic development, since larger individuals seem to feed less frequently on larger prey (Vinson \& Angradi 2011), as observed for Annelida and

Table 4. Dietary categories and their Alimentary Index (AI) for species, size class and season at Camargos reservoir, MG, Brazil. Values higher than 5\% presented in bold, except sand not considered as food item.

\begin{tabular}{|c|c|c|c|c|c|c|c|c|c|c|c|c|c|c|c|c|}
\hline \multirow{2}{*}{$\begin{array}{l}\text { Dietary } \\
\text { categories }\end{array}$} & \multicolumn{8}{|c|}{ Alimentary Index (AI) for I. labrosus } & \multicolumn{8}{|c|}{ Alimentary Index (AI) for $P$. maculatus } \\
\hline & General & Small & Medium & Large & Summer & Autumn & Winter & Spring & General & Small & Medium & Large & Summer & Autumn & Winter & Spring \\
\hline ALG & 0.42 & 2.20 & 2.54 & 0.42 & 0.09 & 0.01 & 1.42 & 0.71 & 0.87 & 0.94 & 0.96 & 0.18 & 0.11 & 0.20 & 2.33 & 1.51 \\
\hline TPL & 4.16 & 0.54 & 0.46 & 0.48 & 1.09 & 10.17 & 2.41 & 2.94 & 5.92 & 5.56 & 6.54 & 2.84 & 9.64 & 9.95 & 2.10 & 3.00 \\
\hline APL & 0.10 & 0.05 & 0.04 & 0.08 & 0.32 & 0.15 & 0.03 & $<0.001$ & 10.11 & 10.26 & 9.85 & 7.04 & 15.37 & 8.28 & 10.27 & 5.97 \\
\hline PRO & 0.25 & 0.90 & 0.48 & 0.02 & 0.02 & 0.002 & 1.00 & 0.51 & 0.004 & 0.005 & 0.005 & 0.006 & 0.002 & 0.003 & 0.005 & - \\
\hline ROT & $<0.001$ & $<0.001$ & $<0.001$ & - & - & $<0.001$ & - & $<0.001$ & 0.02 & 0.01 & 0.05 & 0.08 & 0.002 & 0.02 & 0.04 & 0.03 \\
\hline NEM & 0.93 & 3.28 & 2.57 & 0.18 & 1.41 & 0.15 & 0.25 & 1.12 & 1.19 & 0.94 & 1.70 & 0.19 & 1.34 & 0.68 & 2.66 & 0.40 \\
\hline ANN & 0.07 & 0.008 & 0.79 & 12.14 & 0.12 & - & 0.20 & 0.08 & 0.08 & 0.01 & 0.02 & 1.66 & 0.02 & - & 0.16 & 0.17 \\
\hline $\mathrm{ACA}$ & 0.15 & 0.35 & 0.48 & 0.005 & 0.03 & 0.06 & 0.42 & 0.17 & 0.20 & 0.39 & 0.14 & - & 0.09 & 0.21 & 0.17 & 0.33 \\
\hline $\mathrm{COP}$ & 9.88 & 32.37 & 11.44 & 5.05 & 1.37 & 6.37 & 17.06 & 20.13 & 9.78 & 13.34 & 9.63 & 0.45 & 7.21 & 2.49 & 14.09 & 21.91 \\
\hline CLA & 3.84 & 16.95 & 5.29 & 2.02 & 0.10 & 4.79 & 9.49 & 2.81 & 0.46 & 0.88 & 0.29 & 0.007 & 0.12 & 0.24 & 1.24 & 0.13 \\
\hline OST & 0.44 & 0.07 & 0.12 & 0.02 & 0.10 & 0.38 & 0.91 & 0.41 & 0.10 & 0.27 & 0.03 & 0.01 & 0.15 & 0.06 & 0.15 & 0.03 \\
\hline CHA & 27.13 & 14.85 & 56.74 & 60.25 & 67.00 & 21.93 & 4.90 & 17.53 & 5.90 & 4.89 & 6.69 & 4.43 & 6.61 & 2.82 & 3.07 & 17.97 \\
\hline $\mathrm{CHI}$ & 41.76 & 21.78 & 13.78 & 13.65 & 17.84 & 44.64 & 51.52 & 44.84 & 34.48 & 36.25 & 38.88 & 6.90 & 30.40 & 40.53 & 39.70 & 13.70 \\
\hline OAI & 2.61 & 0.28 & 0.95 & 2.03 & 2.26 & 3.76 & 3.11 & 0.70 & 15.84 & 11.38 & 16.54 & 25.27 & 19.75 & 15.25 & 8.69 & 22.47 \\
\hline TAR & 0.02 & $<0.001$ & $<0.001$ & 0.02 & 0.009 & 0.01 & 0.09 & - & 1.55 & 0.75 & 1.60 & 5.14 & 0.74 & 1.92 & 0.64 & 3.03 \\
\hline FIS & - & - & - & - & - & - & - & - & 10.90 & 11.39 & 4.53 & 44.86 & 5.22 & 15.22 & 11.89 & 7.74 \\
\hline SCL & 0.002 & 0.06 & $<0.001$ & $<0.001$ & - & 0.01 & - & $<0.001$ & 0.12 & 0.29 & 0.04 & 0.02 & 0.28 & 0.15 & 0.03 & 0.09 \\
\hline SAN & 8.25 & 6.30 & 4.33 & 3.61 & 8.23 & 7.56 & 7.20 & 8.07 & 2.44 & 2.44 & 2.49 & 0.91 & 2.95 & 1.98 & 2.78 & 1.53 \\
\hline
\end{tabular}

Codes: ALG: Algae; TPL: Terrestrial plantae; APL: Aquatic plantae; PRO: Protozoa; ROT: Rotifera; NEM: Nematoida; ANN: Annelida; ACA: Acarina; COP: Copepoda; CLA: Cladocera; OST: Ostracoda; CHA: Chaoboridae; CHI: Chironomidae; OAI: Other aquatic insect; TAR: Terrestrial arthropod; FIS: Fish; SCL: Scale and SAN: Sand. 
Silva, Z. et al.

Table 5. Pianka's Index of diet similarity to species, size class and season at Camargos reservoir, MG, Brazil

\begin{tabular}{|c|c|c|c|c|c|}
\hline & I. labrosus- Small & $\begin{array}{l}\text { I. labrosus- } \\
\text { Medium }\end{array}$ & I. labrosus- Large & $\begin{array}{l}\text { P. maculatus- } \\
\text { Small }\end{array}$ & $\begin{array}{l}\text { P. maculatus- } \\
\text { Medium }\end{array}$ \\
\hline \multicolumn{6}{|l|}{ I. labrosus- Small } \\
\hline I. labrosus- Large & 0.44 & 0.97 & & & \\
\hline P. maculatus- Small & 0.66 & 0.37 & 0.32 & & \\
\hline \multirow[t]{2}{*}{ I. labrosus and P. maculatus } & Summer & Autumn & Winter & Spring & \\
\hline & 0.37 & 0.82 & 0.91 & 0.66 & \\
\hline
\end{tabular}

High significant overlaping > 0,6 (Novakowski et al., 2008) in bold.

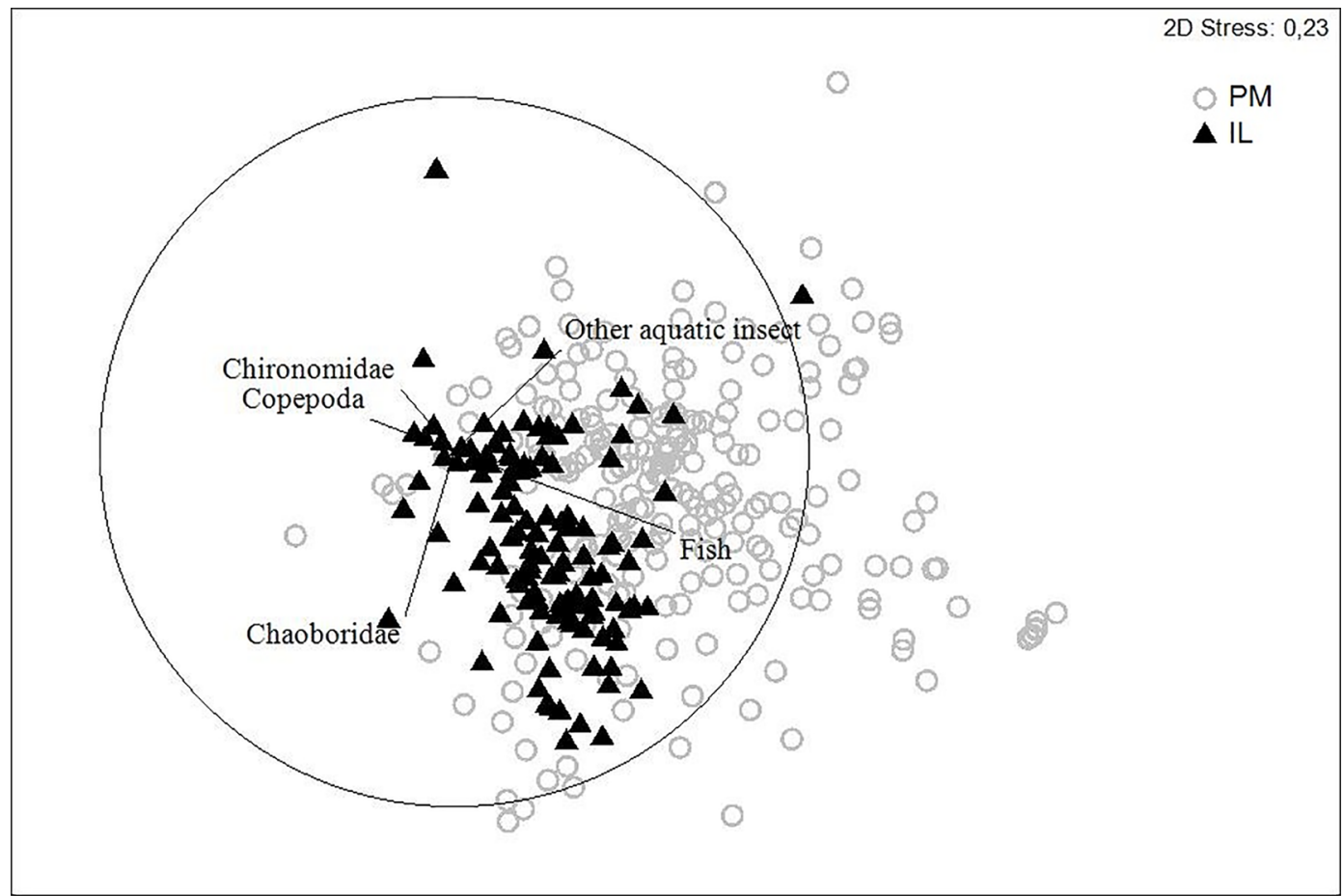

Figure 4. Non-metric multidimensional scaling (NMDS) showing the food resources responsible for the difference between the species I. labrosus and P. maculatus at Camargos reservoir, MG, Brazil

Chaoboridae. Arrington et al. (2002) also observed a greater number of empty stomachs in invertivorous than omnivorous fish.

The spatial scale considered in this study may be responsible for the higher values of biotic factors in the difference between diets, since large-scale studies are more effective in emphasising the regulation of abiotic factors in fish communities (Jackson et al. 2001). Changes in the diet during ontogenetic development reinforce the statement of Vitule et al. (2008) that species may not be an adequate analysis unit per se and ontogeny also need to be evaluated when food habits are compared among species that live in the same area. As for the abiotic factors, the ability to change seasonally the digestive morphology such the intestinal length, intestine weight, and liver weight has already been reported in I. labrosus (D'Anatro et al. 2013). In some species, these changes are reversible and reached in a few days in response to nutritional variations (Gaucher et al. 2012).
In the present study, I. labrosus and P. maculatus showed a diversified diet based on benthic items that corroborate other studies (Basile-Martins et al. 1986, Abes et al. 2001, Fugi et al. 2001, Andrade \& Braga 2005, Ribeiro et al. 2014). The categories Sand and Scale (isolated) should not be considered as part of the diet, but rather as an involuntary intake and confirmation of feeding in the benthic zone as occurred in other fish species that search prey near the bottom (Atobatele \& Ugwumba 2011). Despite this, it is important to note that not only benthic items were found in the stomachs of the studied species. The ingestion of microcrustaceans, Chaoboridae and allochthonous resources indicates the use of the limnetic zone (Câmara et al. 2012) and marginal areas of the reservoir (Agostinho et al. 2008). Feeding habitat expansion was also observed by Dill (1983) and justify by food limitation. Among the studied species, I. labrosus was more associated to the benthic environment in feeding (Abes et al. 2001) and 
ecomorphology (Teixeira \& Bennemann 2007, Masdeau et al. 2011) studies than $P$. maculatus, which has already been associated with different trophic levels (Lobón-Cerviá \& Bennemann 2000).

Our results demonstrated less resource sharing among the species in period of greater trophic abundance, as in the studies of Prejs \& Prejs (1987) and Meschiatti (1995). However, we emphasize that this occurred exclusively in the summer and not during the entire rainy season. The reason for this may be the lack of correspondence between natural periods of drought and rainfall with the low and high levels in reservoirs (Silva et al. 2008), as shown in Fig. 1. The greater richness and abundance values of aquatic insects in reservoir in the rainy-warm season (Câmara et al. 2012) was associated with the increase in water levels, greater external material input and greater habitat heterogeneity (Santana et al. 2015). This occurred in the summer, but not in the spring, which is the season with lowest level of the Camargos reservoir. In addition, the two dry seasons of autumn (where the level of the reservoir is at its highest) and winter had lowest presence of Chaoboridae and Other aquatic insect. This caused the higher intake of common prey such as Chironomidae and Copepoda and greater similarity between diets. The pressure of similar diet in three out of four seasons was reduced by the interspecific diet difference, which was found along the ontogeny. This phenomenon has already been recorded in fish by Frehse et al. (2015) and described as part of a strategy to reduce competition and allow coexistence among related species.

Contextualizing the studied environment during the collection period, which began forty years after its construction, the characteristics of few macrophytes and oxygenated hypolimnion help to explain the relative importance (AI) of the Chaoboridae found, which differs from studies that show greater presence and importance of Chironomidae in reservoirs (Abes et al. 2001, Callisto et al. 2002, Costa et al. 2006, Silva et al. 2015). As the Camargos reservoir ages, I. labrosus, a species with a less diversified and invertivorous diet, is shown to be successful and competitive (Mérona et al. 2003). This may be related to the fact that $I$. labrosus has a lower body mass and uses less allochthonous resources than P. maculatus, a relevant fact in a reservoir with scarce marginal vegetation. Thus, the long period of diet overlap between two of the most fished species and the low fish productivity may indicate the limitation of resources in this reservoir and should be considered from an ecological perspective for future plans of new upstream reservoir construction. In addition, the autochthonous and allochthonous food categories with high common use or low values are supporting information to optimize management and best use of this reservoir.

\section{Acknowledgements}

We thank the data use allowance to Vasco C. Torquato - Rumo Ambiental Consultoria e Serviços LTDA and Agreement CEMIG/ UFLA/FAEPE- Project: Itutinga-Camargos and Alto Rio Grande and its management possibilities, 1991-1995. JRSVitule thanks the research productivity grants from CNPq (JRSV: 310850/2012-6, 303776/2015-3, 302367/2018-7).

\section{Author Contributions}

Zoraia Silva: performed data collection, data analysis and interpretation and writing of the manuscript;
Patrícia Elaine Cunha do Nascimento: data collection and analysis and manuscript preparation.

Jean Ricardo Simões Vitule: data analysis, critical revision and adding intellectual content.

Fabrício de Andrade Frehse: data analysis, critical revision and adding intellectual content.

Mayara Silva Oliveira Ferraz: data analysis and interpretation and manuscript preparation.

Lea Rosa Mourgués-Schurter: contribution in the concept, design of the study and data collection.

\section{Conflicts of interest}

The authors declare that they have no conflict of interest related to the publication of this manuscript.

\section{References}

ABES, S.S., AGOSTINHO, A.A., OKADA, E.K. \& GOMES, L.C. 2001. Diet of Iheringichthys labrosus (Pimelodidae, Siluriformes) in the Itaipu Reservoir, Paraná River, Brazil-Paraguay. Braz. Arch. Biol. Technol. 44 (1):101-105. DOI: $10.1590 / \mathrm{S} 1516-89132001000100014$

ABILHOA, V., VALDUGA, M.O., FREHSE, F.A de \& JEAN R.S. VITULE, J.R.S. 2016. Use of food resources and resource partitioning among five syntopic species of Hypostomus (Teleostei: Loricariidae) in an Atlantic Forest river in southern Brazil. ZOOLOGIA (Curitiba, Online) 33 (6) e20160062. DOI: 10.1590/S1984-4689zool-20160062.

AGOSTINHO, A.A., GOMES, L.C. \& PELICICE, F.M. 2007. Ecologia e Manejo dos Recursos Pesqueiros em Reservatórios do Brasil. EDUEM, Maringá.

AGOSTINHO, A.A., GOMES, L.C., SANTOS, N.C.L., ORTEGA, J.C.G. \& PELICICE, F.M. 2016. Fish assemblages in Neotropical reservoirs: Colonization patterns, impacts and management. Fish. Res. 173 (1): 26-36. DOI: 10.1016/j.fishres.2015.04.006

AGOSTINHO, A.A., PELICICE, F.M. \& GOMES, L.C. 2008. Dams and the fish fauna of the Neotropical region: impacts and management related to diversity and fisheries. Braz. J. Biol. 68 (4, Suppl.): 1119-1132. DOI: 10.1590/S1519-69842008000500019

ALBRECHT, M.P., CARAMASCHI E.P. \& HORN M.H. 2009. Population responses of two omnivorous fish species to impoundment of a Brazilian tropical river. Hydrobiologia 627: 181-193. DOI: 10.1007/s10750-0099727-7

ANDERSON, M.J., GORLEY, R.N. \& CLARKE, K.R. 2008. PERMANOVA+ for Primer: Guide to Software and Statistical Methods. Primer-E, Plymouth.

ANDRADE, P.M. \& BRAGA, F.M.S. 2005. Diet and feeding of fish from Grande river, located below the Volta Grande Reservoir, MG - SP. Braz. J. Biol. 65 (3): 377-385. DOI: $10.1590 / \mathrm{S} 1519-69842005000300002$

ANTUNES, F.Z. 1986. Caracterização climática do Estado de Minas Gerais. Informe Agropecuário, Belo Horizonte, 12 (138): 9-13.

ARAÚJO, F.G., ANDRADE, C.C., SANTOS, R.N., SANTOS, A.F.G.N. \& SANTOS, L.N. 2005. Spatial and seasonal changes in the diet of Oligosarcus hepsetus (Characiformes, Characidae) in a Brazilian Reservoir. Braz. J. Biol 65 (1): 1-8. DOI: 10.1590/S1519-69842005000100002.

ARAÚJO-LIMA, C.A.R.M., AGOSTINHO, A.A. \& FABRÉ, N.N. 1995. Trophic aspects of fish communities in Brazilian rivers and reservoirs, pp. 105-136. In: J.G. Tundisi, C.E.M. Bicudo \& T. Matsumura-Tundisi (eds.), Limnology in Brazil. ABC/SBL, Rio de Janeiro.

ARCIFA, M.S., GOMES, E.A.T. \& MESCHIATTI, A.J. 1992. Composition and fluctuations of the zooplankton of a tropical Brazilian reservoir. Arch. Hydrobiol. 123: 479-495.

ARCIFA M.S., NORTHCOTE, T.G. \& FROEHLICH, O. 1991. Interactive ecology of two cohabiting characin fishes (Astyanax fasciatus and Astyanax bimaculatus) in an eutrophic Brazilian reservoir. J. Trop. Ecology 7 (2): 257-268. DOI: $10.1017 / \mathrm{S} 0266467400005423$ 
ARRINGTON, D.A., WINEMILLER, K.O., LOFTUS, W.F. \& AKIN, S. 2002. How often do fishes "Run on empty"? Ecology 83 (8): 2145-2151. DOI: $10.2307 / 3072046$

ATOBATELE, O.E. \& UGWUMBA, O.A. 2011. Condition factor and diet of Chrysichthys nigrodigitatus and Chrysichthys auratus (Siluriformes: Bagridae), from Aiba reservoir, Iwo, Nigeria. Rev. Biol. Trop. 59 (3): 1233-1244.

BASILE-MARTINS, M.A., CIPÓLLI, M.N. \& GODINHO, H.M. 1986. Alimentação do mandi Pimelodus maculatus Lacépède, 1803 (Siluriformes, Pimelodidae), de trechos dos rios Jaguari e Piracicaba, São Paulo - Brasil. Bol. Inst. Pesca 3: 17-29.

BONATO K.O. \& FIALHO C.B. 2014. Evidence of Niche Partitioning under Ontogenetic Influences among Three Morphologically Similar Siluriformes in Small Subtropical Streams. PLOS ONE 9 (10): e110999. DOI:10.1371/ journal.pone.0110999

BRAGA, R.R., BORNATOWSKI, H. \& VITULE, J.R.S. 2012. Feeding ecology of fishes: an overview of worldwide publications. Rev. Fish. Biol. Fisheries 22 (4): 915-929. DOI: 10.1007/s11160-012-9273-7

CALLISTO, M., VONO, V., BARBOSA, F.A.R. \& SANTEIRO, S.M. 2002. Chironomidae as a food resource for Leporinus amblyrhynchus (Teleostei: Characiformes) and Pimelodus maculatus (Teleostei: Siluriformes) in a Brazilian reservoir. Lundiana 3 (1): 67-73.

CÂMARA, C.F., CASTILHO-NOLL, M.S.M. \& ARCIFA, M.S. 2012. Predation on microcrustaceans in evidence: the role of Chaoborid larvae and fish in two shallow and small Neotropical reservoirs. Nauplius 20 (1): 1-14. DOI: 10.1590/S0104-64972012000100002

CHIPPS, S.R \& GARVEY, J.E. 2007. Quantitative assessment of food habits and feeding patterns. In GUY, C.S \& BROWN, M.L. (eds) Analysis and interpretation of freshwater fisheries data. American Fisheries Society, Bethesda. p. 473-514.

CLARKE, K.R. \& GORLEY, R.N. 2006. PRIMER v6: User Manual/Tutorial. PRIMER-E, Plymouth.

COSTA, F.L.M., OLIVEIRA, A. \& CALLISTO, M. 2006. Inventário da diversidade de macroinvertebrados bentônicos no reservatório da estação ambiental de Peti, MG, Brasil. Neotrop. Biol. Conserv. 1 (1): 17-23.

D'ANATRO, A., VIDAL, N., GONZÁLEZ-BERGONZONI, I., MELLO, F.T., TANA, J. \& NAYA, D.E. 2013. Geographic and seasonal variation analysis of digestive morphology in the catfish Iheringichthys labrosus along lower Río Uruguay. Open Access Anim. Physiol. 5: 9-13. DOI: 10.2147/OAAP. S47193

DILL, L.M. 1983. Adaptive flexibility in the foraging behavior of fishes. Can. J. Fish. Aquat. Sci. 40 (4): 398-408. DOI: 10.1139/f83-058

FAGUNDES, C.K., BEHR, E.R. \& KOTZIAN, C.B. 2008. Diet of Iheringichthys labrosus (Siluriformes, Pimelodidae) in Ibicuí River, Southern Brazil. Iheringia, Sér. Zool. 98 (1): 60-65. DOI:10.1590/S0073-47212008000100008

FREHSE, F.A., VALDUGA, M.O., CORRÊA, M.F.M., PINHEIRO, P.C. \& VITULE, J.R.S. 2015. Feeding ecology and resource sharing patterns between Stellifer rastrifer (Jordan, 1889) and S. brasiliensis (Schultz, 1945) (Perciformes: Sciaenidae) along the coasts of Paraná and Santa Catarina, Brazil. J. Appl. Ichthyol. 31 (3): 479-486. DOI: 10.1111/jai.12768

FUGI, R., AGOSTINHO, A.A. \& HAHN, N.S. 2001. Trophic morphology of five benthic-feeding fish species of a tropical floodplain. Rev. Bras. Biol. 61 (1): 27-33. DOI: 10.1590/S0034-71082001000100005

FUGI, R., HAHN, N.S., \& AGOSTINHO, A.A. 1996. Feeding styles of five species of bottom feeding fishes of the high Paraná river. Environ. Biol. Fishes 46 (3): 297-307. DOI: 10.1007/BF00005006

GAUCHER, L., VIDAL, N., D'ANATRO, A. \& NAYA, D.E. 2012. Digestive flexibility during fasting in the characid fish Hyphessobrycon luetkenii. J. Morphol. 273 (1): 49-56. DOI: 10.1002/jmor.11005

GUIMARÃES, D.P., REIS, R.J.R. \& LANDAU, E.C. 2010. Índices pluviométricos em Minas Gerais. Embrapa Milho e Sorgo. Boletim de Pesquisa e Desenvolvimento, 30. Sete Lagoas, MG.

HAHN, N.S. \& FUGI, R. 2007. Alimentação de peixes em reservatórios brasileiros: alterações e consequências nos estágios iniciais do represamento. Oecol. Bras. 11 (4): 469-480. DOI: 10.4257/oeco.2007.1104.01
HYNES, H.B.N. 1950. The food of fresh-water Sticklebacks Gasterosteus aculeatus and Pygosteus pungitius, with a review of methods used in studies of the food of fishes. J. Anim. Ecol. 19 (1): 36-58. DOI: 10.2307/1570

IPT. INSTITUTO DE PESQUISAS TECNOLÓGICAS DO ESTADO DE SÃO PAULO. 2008. Diagnóstico da situação dos recursos hídricos na Bacia Hidrográfica do Rio Grande, SP/MG. São Paulo. (Relatório técnico ${ }^{\circ}$ 96.581-205). http://www.sigrh.sp.gov.br/public/uploads/documents/7113/ diagnostico_sintese.pdf

JACKSON, D.A., PERES-NETO, P.R. \& OLDEN, J.D. 2001. What controls who is where in freshwater fish communities - the roles of biotic, abiotic, and spatial factors. Can. J. Fish. Aquat. Sci. 58 (1): 157-170. DOI: 10.1139/ f00-239

KAWAKAMI, E. \& VAZZOLER, G. 1980. Método gráfico e estimativa de índice alimentar aplicado no estudo de alimentação de peixes. Bol. Inst. Oceanogr. 29 (2): 205-207. DOI: 10.1590/S0373-55241980000200043

LOBÓN-CERVIÁ, J. \& BENNEMANN, S. T. 2000. Temporal trophic shifts and feeding diversity in two sympatric, neotropical omnivorous fishes: Astyanax bimaculatus and Pimelodus maculatus in Rio Tibagi (Paraná, Southern Brazil). Arch. Hydrobiol. 149 (2): 285-306. DOI: 10.1127/archivhydrobiol/149/2000/285.

LUNDBERG, J.G. \& LITTMANN, M.W. 2003. Family Pimelodidae (Longwhiskered catfishes). In REIS, R.E., KULLANDER, S.O. \& FERRARIS, C.J.Jr. (Org.). Check list of the freshwater fishes of South and Central America. EDIPUCRS, Porto Alegre, p. 432-446.

LUZ-AGOSTINHO, K.D.G., BINI, L.M., FUGI, R., AGOSTINHO, A.A. \& JÚLIO, H. F. 2006. Food spectrum and trophic structure of the ichthyofauna of Corumbá reservoir, Paraná river Basin, Brazil. Neotrop. Ichthyol. 4 (1): 61-68. DOI: 10.1590/S1679-62252006000100005

MAGNAN, P., RODRÍGUEZ, M.A., LEGENDRE, P. \& LACASSE, S. 1994. Dietary Variation in a Freshwater Fish Species: Relative Contributions of Biotic Interactions, Abiotic Factors, and Spatial Structure. Can. J. Fish. Aquat. Sci. 51 (12): 2856-2865. DOI: 10.1139/f94-284

MANETTA, G.I., BENEDITO-CECILIO, E. \& MARTINELLI, L.C. 2003. Carbon sources and trophic position of the main species of fishes of Baía, Paraná river floodplain, Brazil. Braz. J. Biol. 63 (2): 283-290. DOI: 10.1590/ S1519-69842003000200013

MARTINS, M.M., MENDONCA, H.S., RODRIGUES, S.S. \& ARAÚJO, F.G. 2017. Trophic ecology of two syntopic sciaenid species (Micropogonias furnieri (Desmarest, 1823) and Ctenosciaena gracilicirrhus) (Metzelaar, 1919) in a tropical bay in south-eastern Brazil. J. Appl. Ichthyol. 33 (4): 740-745. DOI:10.1111/jai.13360

MASDEU, M., FRANCO, T.M., LOUREIRO, M. \& ARIM, M. 2011. Feeding habits and morphometry of Iheringichthys labrosus (Lütken, 1874) in the Uruguay River (Uruguay). Neotrop. Ichthyol. 9 (3): 657-664. DOI: 10.1590/ S1679-62252011005000034.

MÉRONA, B., VIGOUROUX, R. \& HOREAU, V. 2003. Changes in food resources and their utilization by fish assemblages in a large tropical reservoir in South America (Petit-Saut Dam, French Guiana). Acta Oecol. 24 (3): 147-156. DOI: 10.1016/S1146-609X(03)00065-1

MESCHIATTI, A.J. 1995. Alimentação da comunidade de peixes de uma Lagoa Marginal do rio Mogi Guaçu, SP. Acta Limonol. Bras. 8: 115-137.

NOMURA, H., POZZI, R. \& MANREZA, F.A. 1972. Caracteres merísticos e dados biológicos sobre o mandi-amarelo, Pimelodus clarias (Bloch, 1782), do Rio Mogi-Guaçu (Pisces, Pimelodidae). Rev. Bras. Biol. 32 (1):1-14.

NOVAKOWSKI, G.C., HAHN, N.S. \& FUGI, R. 2008. Diet seasonality and food overlap of the fish assemblage in a Pantanal pond. Neotrop. Ichthyol. 6 (4): 567-576. DOI: 10.1590/S1679-62252008000400004

PAMPLIN, P.A.Z., ALMEIDA, T.C.M. \& ROCHA, O. 2006. Composition and distribution of benthic macroinvertebrates in Americana Reservoir (SP, Brazil). Acta Limnol. Bras. 18 (2):121-132.

PIANKA, E.R. 1974. Niche overlap and diffuse competition. Proc. Natl Acad. Sci. USA 71 (5): 2141-2145. DOI: 10.1073/pnas.71.5.2141

PREJS, A. \& COLOMINE, G. 1981. Métodos para el estudio de los alimentos y las relaciones tróficas de los peces. Universidad Central de Venezuela. Caracas. 
PREJS, A. \& PREJS, K. 1987. Feeding of tropical freshwater fishes: seasonality in resource availability and resource use. Oecologia 71 (3): 397-404. DOI: 10.1007/BF00378713

RIBEIRO, A.R., BIAGIONI, R.C. \& SMITH, W.S. 2014. Estudo da dieta natural da ictiofauna de um reservatório centenário, São Paulo, Brasil. Iheringia, Sér. Zool. 104 (4): 404-412. DOI:10.1590/1678-476620141044404412

ROSS S.T. 1986. Resource partitioning in fish assemblages: a review of field studies. Copeia 2: 352-388.

SANTANA, H.S., SILVA, L.C.F., PEREIRA, C.L., SIMIÃO-FERREIRA, J. \& ANGELINI, R. 2015. The rainy season increases the abundance and richness of the aquatic insect community in a Neotropical reservoir. Braz. J. Biol. 75 (1): 144-151. DOI:10.1590/1519-6984.09213

SÁ-OLIVEIRA, J.C., ANGELINI, R., ISAAC-NAHUM, V.J. 2014. Diet and niche breadth and overlap in fish communities within the area affected by an Amazonian reservoir (Amapá, Brazil). An. Acad. Bras. Ciênc. 86 (1): 383-405. DOI: 10.1590/0001-3765201420130053

SILVA, C.C., FERREIRA, E.J.G. \& DEUS, C.P. 2008. Dieta de cinco espécies de Hemiodontidae (Teleostei, Characiformes) na área de influência do reservatório de Balbina, rio Uatumã, Amazonas, Brasil. Iheringia, Sér. Zool. 98 (4): 464-468. DOI: 10.1590/S0073-47212008000400008

SILVA, E.L., FUGI, R. \& HAHN, N.S. 2007. Variações temporais e ontogenéticas na dieta de um peixe onívoro em ambiente impactado (reservatório) e em ambiente natural (baia) da bacia do Rio Cuiabá. Acta sci. 29 (4): 387-394. DOI: $10.4025 /$ actascibiolsci.v29i4.878
SILVA, J.S.; ALBERTONI, E.F. \& PALMA-SILVA, C. 2015. Temporal variation of phytophilous Chironomidae over a 11-year period in a shallow Neotropical lake in southern Brazil. Hydrobiologia 742 (1): 129-140. DOI: 10.1007/s10750-014-1972-8

SISÁGUA - Sistema de Informação de Qualidade da Água dos Reservatórios da Cemig. http://www2.cemig.com.br/sag/SAG. Accessed 03/04/2018.

TEIXEIRA, I. \& BENNEMANN, S. T. 2007. Ecomorfologia refletindo a dieta dos peixes em um reservatório no sul do Brasil. Biota Neotrop. 7 (2): 67-76. DOI: 10.1590/S1676-06032007000200007. http://www.biotaneotropica.org. br/v7n2/pt/fullpaper?bn00807022007+pt (último acesso em 10/07/2018).

TUNDISI, J. G. \& MATSUMURA-TUNDISI, T. 2003. Integration of research and management in optimizing multiple uses of reservoirs: the experience in South America and Brazilian case studies. Hydrobiologia 500 (1-3): 231-242.

VINSON, M.R. \& ANGRADI, T.R. 2011. Stomach Emptiness in Fishes: Sources of Variation and Study Design Implications. Rev. Fish. Sci. 19 (2): 63-73. DOI: $10.1080 / 10641262.2010 .536856$

VITULE, J.R.S., BRAGA, M.R. \& ARANHA, J.M.R. 2008. Ontogenetic, spatial and temporal variations in the feeding ecology of Deuterodon langei Travassos, 1957 (Teleostei: Characidae) in a Neotropical stream from the Atlantic rainforest, southern Brazil. Neotrop. Ichthyol. 6 (2): 211-222. DOI: 10.1590/S1679-62252008000200008.

WOOTTON, R.J. 1992. Fish ecology. Chapman and Hall, New York. 